\title{
Thyrotomyにより摘出した喉頭金属異物例
}

\author{
大 城 康 司 $^{1,2)}$. 東川 雅 彦 ${ }^{2)}$. 竹 中 洋 ${ }^{2}$
}

\section{A Case of a Foreign Body of the Larynx Removed by Thyrotomy}

\author{
Koji Oshiro ${ }^{1,2)}$, Masahiko Higasikawa ${ }^{2)}$ and Hirosi Takenaka ${ }^{2)}$
}

A 22-years-old male complained of neck pain while using a lawn mower. He found a skin injury on the front of his neck. Computed tomography discovered a foreign body within the thyroid cartilage, which did not reach to the membrane of the larynx. He underwent a "thyrotomy" and a tracheostomy under general anesthesia. We found a foreign body that was burying under the thyroarytenoid muscle. It was made of metal and was $1 \mathrm{~cm}$ length. No functional disturbance was observed after the surgery.

Key words：喉頭外傷, 異物, thyrotomy

\section{はじめに}

気道異物のなかで喉頭異物は比較的稀である ${ }^{1)}$. 異物自 体による気道閉塞や異物反応による喉頭粘膜浮腫からの気 道狭窄・閉塞の可能性を考え, 十分な観察と的確な好置を 必要とする. 患者の年齢や状態, 異物の種類 - 大きさ・形・ 位置, さらには異物により生じた喉頭外傷の有無等で予後 は大きく変化する．したがって初期の状況把握は正確かつ 迅速であるべきであり, それを遂行するための問診や検査 は的確になされる必要がある。

今回，金属異物が頸部より刺入し，甲状軟骨を穿通し， 喉頭内腔に達しないまでも甲状披裂筋内にとどまった状態 で治療をおこなった症例を経験した。症例を呈示するとと もに摘出法についての考察を加えた.

症例

症例：22歳，男性

現病歴：平成14年 8 月 19 日午前 9 時頃, 土木作業現場で 草刚機による雑草の除去作業中, 突然何かが前頸部に刺さっ た感触を自覚した．前頸部に疼痛が続くため近医耳鼻咽喉 科を受診した。画像上, 甲状軟骨内側に金属と思われる異 物を認めたため, 異物除去目的で大阪医科大学耳鼻咽喉科 を紹介された。

前頸部正中やや右側に異物の刺入跡と思われる傷を認め たが，出血や腫脹はなかった（図 1 ）。呼吸困難感はなく 軽度の前頚部痛と嚥下時痛を認めるのみであった。喉頭内 視鏡検査（図 2 ）では, 左仮声帯の軽度の発赤・腫脹を認 めた. 声帯の可動性は良好であった. 喉頭内腔の粘膜損傷

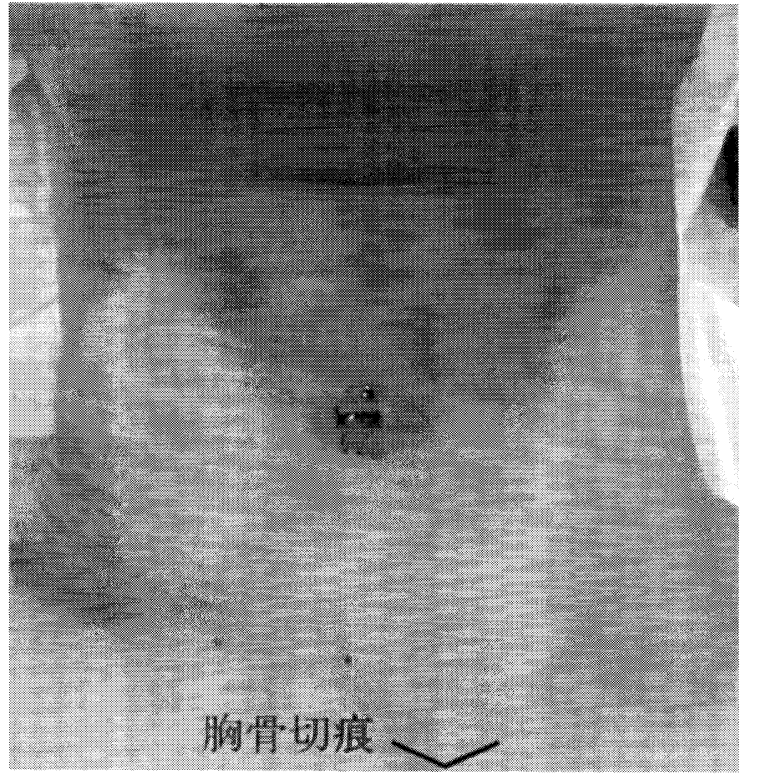

図 1 前頸部正面像

正中やや右側に異物の刺入跡と思われる傷を認める.

を思わせる所見は認めなかった.

異物が金属であることが確実であったので，破傷風の予

防（破傷風トキソイドの筋肉注射）を施したのち，入院の

うえ加療をすすめた。

画像所見：頸部の単純レントゲン（図 3 ) では頸部正中 左側，声門レベルに異物を認めた.

頸部単純 CT（図 4) では, 異物は甲状軟骨を貫き喉頭 内腔へと向かっていた. 粘膜下気腫が存在しないことから

1 ）洛和会音羽病院耳鼻咽喉科

2 ) 大阪医科大学耳鼻咽喉科学教室

1 ) Otowa Hospital, Kyoto

2 ) Department of Otolaryngology, Oosaka Medical College, Oosaka 
喉頭内腔には達しておらず，粘膜下にとどまっていること が尒想された。

手術所見：以上の所見から, 頸部外切開により喉頭内腔 に損傷を与えず異物を摘出する経路が最良の策と判断した。

全身麻酔下に, 皮膚切開線は甲状軟骨中央レベルの横切 開においた。甲状軟骨板を露出した時点では異物あるいは 軟骨の刺入点は明視下になかった。次に甲状軟骨正中の右 側下方を $1 \mathrm{~cm}$ 四方開空し (図 5-a), 甲状披裂筋を一部切 開しつつ探索したところ, 筋内に埋もれた異物を認め, こ

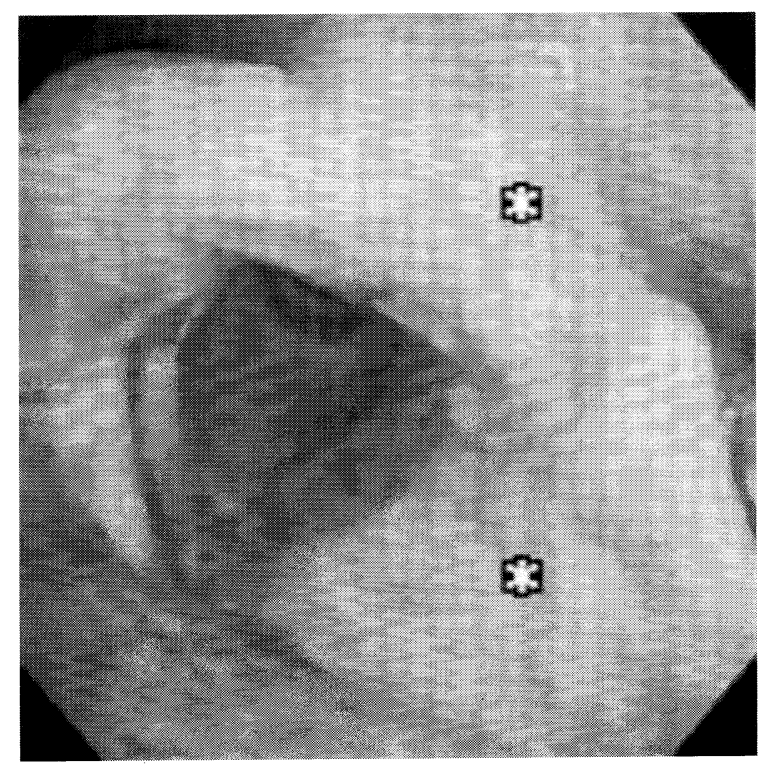

図 2 喉頭内視鏡像

左仮声带の軽度の発赤・腫脹を認める.
れを摘出した（図 5-b). 術後の粘膜浮腫による気道閉塞も 予想され，気管切開術を追加し手術を終了した。

術後経過: 術後は喉頭粘膜の浮腫は軽度で, 声帯運動も 保たれていた。術後 2 日目で気管カニューレ抜去し, 術後 6 日目気管孔が閉鎖した時点で退院となった，退院後は受 診の指示をしたにもかかわらず受診はないため経過は不明 であるが, 紹介元も含めてトラブルの報告は受けていない.

考

察

喉頭異物の臨床像は，異物のみならず，異物による損傷 が直接気道に影響を与えることから，喉頭異物と喉頭外傷 の二面性を併せ持ち, この両者について同時にかつ迅速に 対応する必要がある．特に今回我々が経験した症例では， 異物による気道閉塞が十分に予想される例であり, 慎重な 対応が必要であった。

一般に喉頭外傷は, 喉頭内腔からの損傷である内損傷と, 外頸部からの損傷である外損傷に分けられる. 外損傷はさ らに開放性損傷と閉鎖性損傷とに分けられる。今回の症例 では内腔への直接損傷がなかったことから，閉鎖性損傷と しての取り扱いを必要とした，閉鎖性損傷は受傷直後に異 常を認めなくとも，時間の経過とともに浮腫の進行等で上 気道の狭窄をきたすことがあり ${ }^{2,3)}$, 経時的な変化を捉え ることが肝要である。ステロイド剤や消炎剂の投与は, 浮 腫の予防・改善に優れた効果を発揮するが, 浮腫が進行し てからの投与では不幸な転帰をたどることがあるため予防 投与が望ましい. また粘膜損傷に始まった感染は重篤化す ると頸部蜂窩織炎, 深頸部膿瘍を引き起こし, さらには縦 隔洞炎・膿瘍にまで進行することもあるため抗生剤投与は 不可欠である，外損傷ではさらに破傷風に対する措置も重

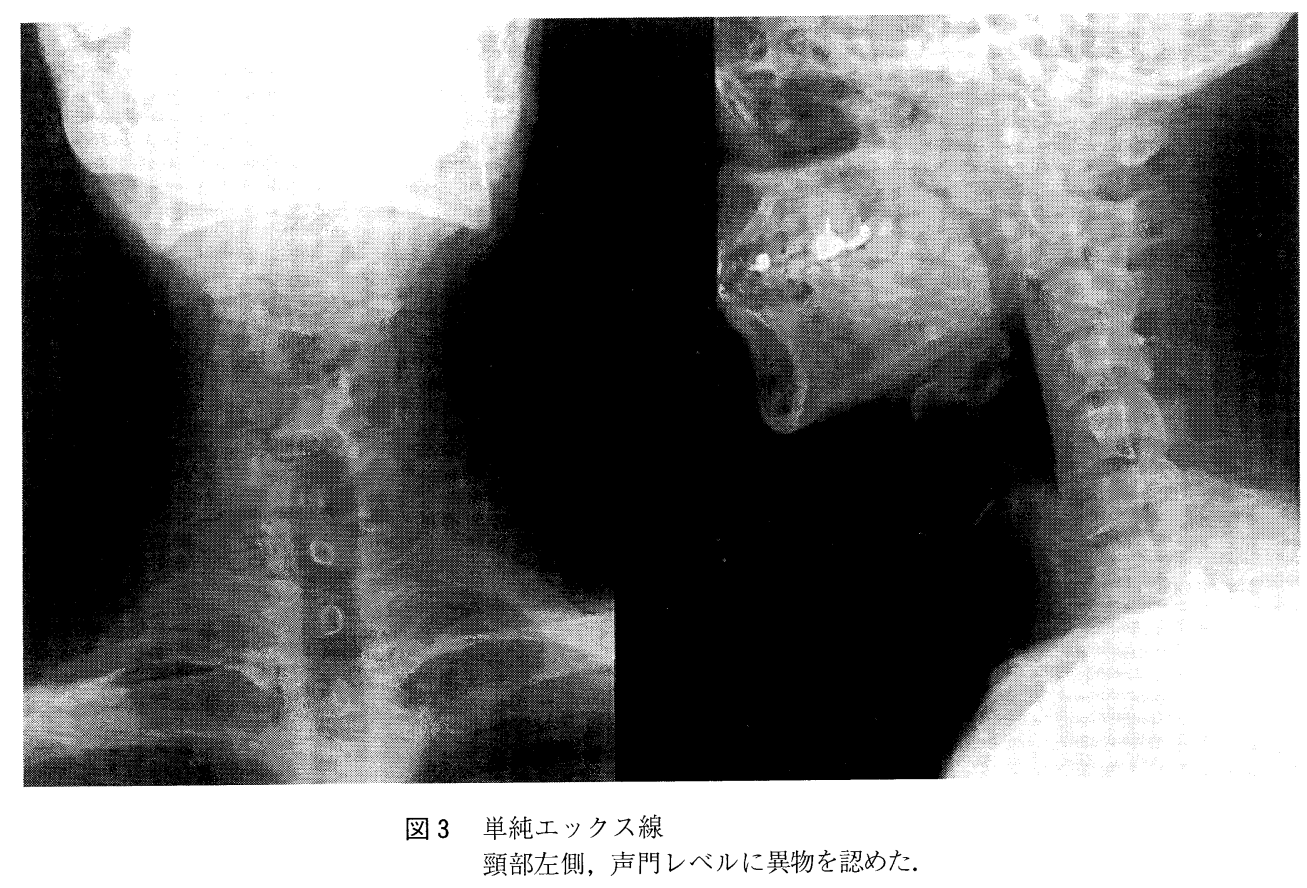


要である. 今回はステロイド剤, 抗生剤等の点滴加療で浮 腫の進行を抑え，早急に異物の除去を行ったため幸いにも 浮腫による上気道の狭窄や重篤な感染は認めなかった。

今回㧍こなった thyrotomy とは, 日本喉頭科学会用語 委員会 ${ }^{4)}$ によると, 外切開にて甲状軟骨を切開するが喉頭 内腔には手技が及ばないアプローチの手段である。一方，

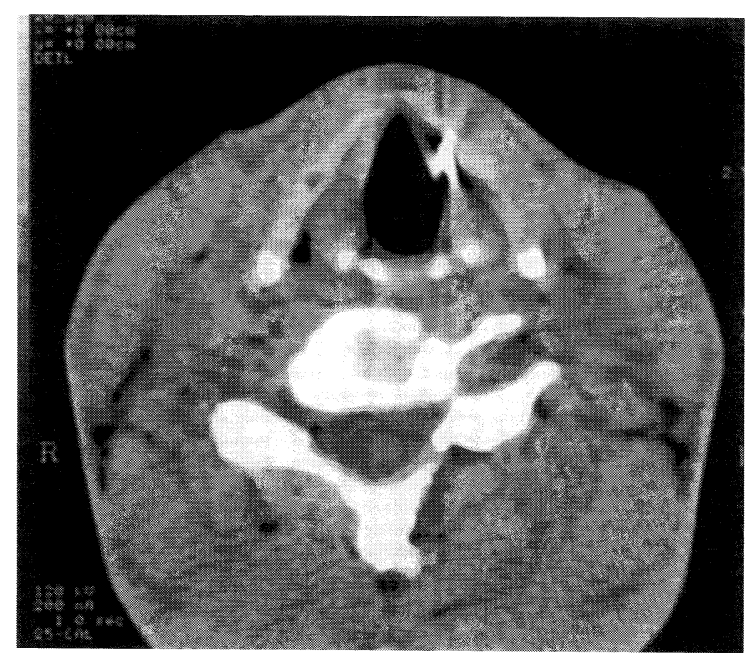

図 4 頸部単純 $\mathrm{CT}$

甲状軟骨内側に異物を認める。異物は喉頭内腔には 達していない. 明らかな気腫は認めなかった。
甲状軟骨を切開し喉頭内腔に入るアプローチは laryngotomy, 甲状軟骨と輪状軟骨を正中離断し喉頭内 腔に入るアプローチは laryngofissure の名称で定義され ている.今回の症例では, 喉頭内視鏡所見から喉頭粘膜の 損傷を認めなかったこと, 画像診断上異物が粘膜下に止まっ ていると診断できたことから thyrotomy の選択となった. 内腔への侵襲が最小限であり, 妥当な選択であったと考え ている. 気管切開術の追加は, 甲状披裂筋への侵襲度が大 きかったので, 気道確保の観点から施行した。甲状披裂筋 への侵襲が軽微であれば追加せずに経過できる例もあると 思われるが, 受傷直後は確実な対応が要求されるので気管 切開施行はためらうべきではないと考える. 一方, 粘膜損 傷を認める症例では laryngotomy や laryngofissure の 検討が迫られる。いずれも例においても喉頭ファイバーゃ $\mathrm{CT}$ 等の画像診断から異物の場所, 周囲への影響を正確に そして迅速に診断することが重要であると考える.

今回の症例では, 皮虐の刺入部と異物の位置にはかなり の距離 $(20 \mathrm{~mm}$ 程度) を認めた. 断定はできないが, 受傷 時に頸部を左に回旋していたと思われる. 摘出の際に刺入 部の位置にこだわると, 不要な切開を加えたり, 異物の場 所の同定に差支えが生じたりする。十分な問診から状況を 把握し, 視診のみでなく画像上からも異物の位置を正確に とらえたうえで, 適切な手術手技を選択することが肝要で あると考えた。

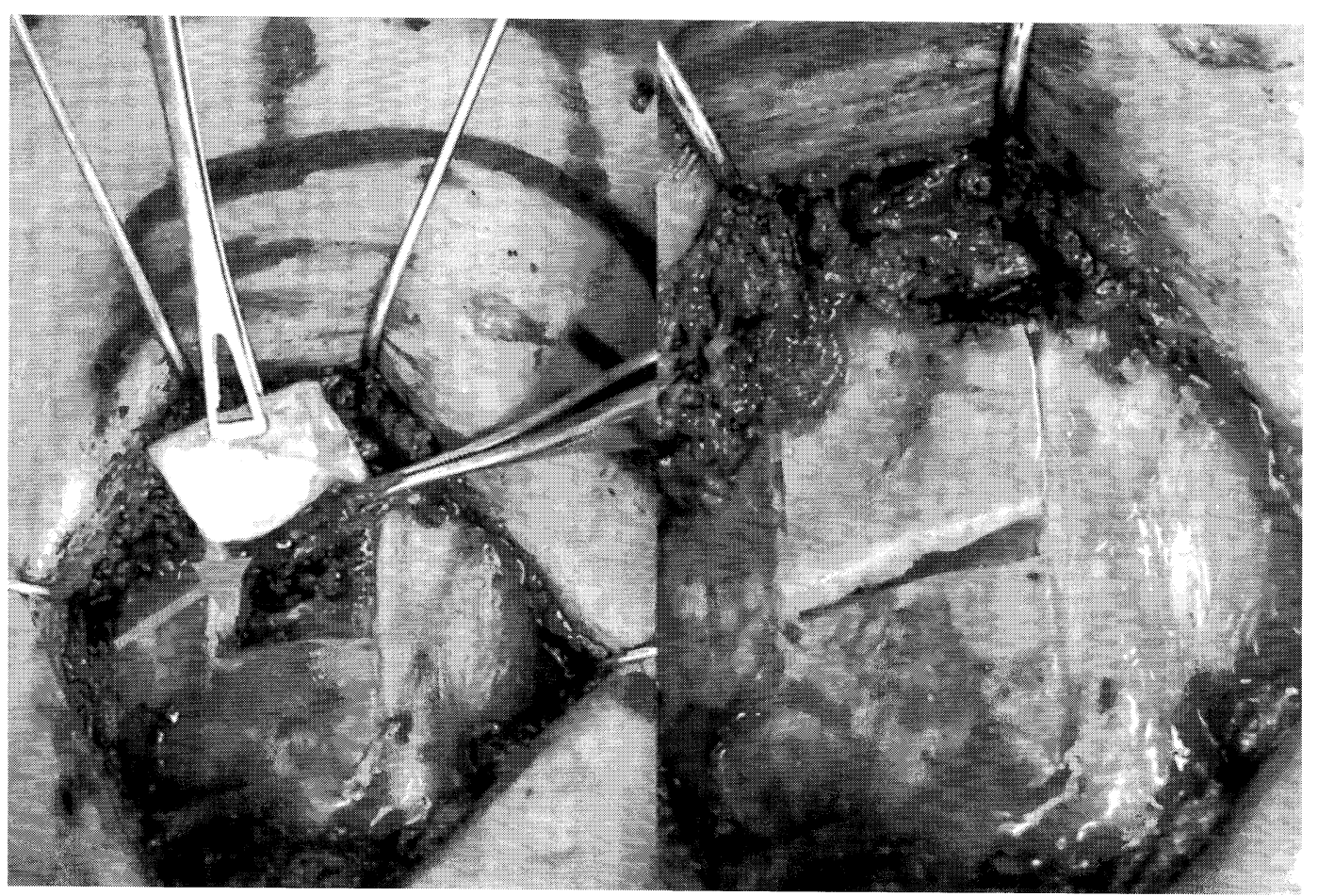

b

a

図 5 手術所見

甲状軟骨正中の右側下方を $1 \mathrm{~cm}$ 四方コの字状に開空し（図 5-a)，甲状披裂筋内に埋もれた異物を認 めた（図 5-b). 
ま と め

頸部より刺入し喉頭粘膜下にとどまった異物症例を経験 した. 異物は thyrotomyにより喉頭機能障害を残すこと なく摘出できた.

$$
\text { 参 考 文 献 }
$$

1）久 育男：喉頭異物症 - 喉頭外傷. 耳鼻咽喉科 ·頭 頸部外科 MOOK $23: 48 \sim 54$, 金原出版, 東京, 1992.
2）丘村 照：咽頭異物 - 喉頭異物. JOHNS 7 ：1292 1296, 1991.

3）志藤文明：咽喉頭の外傷. JOHNS 7 ：1297 1303, 1991.

4) 用語委員会報告. 日本喉頭科学会 用語委員会（小宮 山荘太郎他)。喉頭 $11: 84 \sim 86,1999$.

別刷請求先 $\mathbf{1} 607-8062$ 京都市山科区音羽珍事町 2 洛和会音羽病院耳鼻咽喉科 大城康司 